\title{
Kedudukan dan peranan hukum adat dalam penyelesaian konflik
}

\author{
Harry Saputra $^{1 *}$, Mulia Jaya ${ }^{2}$, Siti Maryam ${ }^{3}$ \\ ${ }^{123}$ Fakultas Ilmu Sosial dan Ilmu Politik, Universitas Muara Bungo \\ *Korespondensi Penulis
}

\section{Informasi Artikel Abstrak}

\section{Kata Kunci : \\ Hukum Adat \\ Kedudukan \\ Peranan \\ Konflik \\ Penyelesaian}

Histori Artikel :
Setiap daerah di Indonesia memiliki adat istiadat yang berbeda-beda, tak terkecuali di Dusun Talang Silungko Kacamatan Bathin II Pelayang. Biasanya hokum adat di masing-masing daerah tersebut digunakan salah satunya sebagai aturan dalam menyelesaikan konflik di daerah tersebut. Penelitian ini bertujuan untuk menganalisis bagaimana kedudukan dan peranan hokum adat dalam menyelesaikan konflik di Dusun Talang Silungko Kecamatan Bathin II Pelayang Kabupaten Bungo. Penelitian ini merupakan penelitian deskriptif kualitatif. Hasil penelitian menunjukkan bahwa Kedudukan Hukum Adat Di Dusun Talang Silungko terbagi menjadi 3 (tiga) yaitu a) Pucuk Undang; b) Hukum Publik; dan c) Hukum Privat. Namun demikian, ketiganya mempunyai ruang atau wilayanh pengaturannya masing-masing, sehingga dalam mengimplementasikan hukum adat tidak tumpang tindih. Secara tegas memberi pemahaman bahwa kedudukan adat itu di bawah hukum Agama (Islam) atau syarak. Sedangkan hambatannya adalah adanya sedikit pro dan kontra didalam penerapan dilapangan dan itu merupakan hal yang wajar didalam kehidupan bermasyarakat dan belum memiliki dana sendiri atau dana rutin.

Copyright (C) 2019 Jurnal Politik dan Pemerintahan Daerah 
Vol 1, No 1, Juni 2019, pp. 17-29

\section{Pendahuluan}

Kebudayaan masyarakat merupakan cikal-bakal lahirnya sebuah peraturan-peraturan terkait dengan adat/ kebiasaan tertentu dan lebih banyak disebut dengan kearifan local (local of law). Maka dari itu dengan beragamnya kebudayaan yang ada di Indonesia maka semakin banyak pula aturanaturan/ hukum terkait dengan adat/ kebiasaan dalam kelompok masyarakat tertentu. Hukum adat muncul berdasarkan perilaku-perilaku kelompok masyarakat tersebut yang dilakukan dalam kegiatan sehari-hari sehingga menjadi sebuah kebiasaan pribadi yang kemudian ditiru oleh sebagian besar kelompok masyarakat sehingga kebiasaan tersebut lambat laun menjadi adat.

Masyarakat di provinsi Jambi merupakan masyarakat adat melayu yang disebut dengan masyarakat Melayu Jambi. Di provinsi ini adat istiadat Melayu sangat dominan. Dan orang Melayu Jambi mayoritas adalah pemeluk agama Islam. Mereka memiliki prinsip "adat bersendi syarak, syarak bersendi kitabullah", artinya "segala ketentuan yang mengatur kehidupan dalam masyarakat berasal dari budaya Ninik moyang dan bersumber dari ajaran-ajaran agama, yaitu Al Quran dan dan Hadits" (Buku Pedoman Adat Bungo,2004:1)

Secara historis kita mengetahui bahwa masyarakat adat adalah suatu entitas sosio-kultural yang mengatur diri sendiri (self-governing). Melalui lembaga dan acuan adat yang dimiliki, identitas lokal diekspresikan, dan kepentingan kolektif di komunitas tersebut dikelola. Dalam situasi seperti inilah kita bisa melihat kelompok suku atau masyarakat adat dalam coraknya yang asli.

Di kabupaten Bungo masyarakat adat sudah ada sejak zaman dahulu sampai sekarang. Masyarakatnya dituntut oleh adat istiadat yang dipegang oleh Ninik Mamak secara turun temurun dan dipatuhi dalam wilayah persekutuan Hukum Adat Bungo (Buku Pedoman Adat Bungo,2004 :1). Perkembangan adat istiadat di Kabupaten Bungo cukup lama sejak zaman penjajahan Belanda yang dihuni oleh orangorang suku Batin. Menurut H.M Thaib, RH (Buku Pedoman Adat Bungo, 2004:1) menyebutkan orang batin itu adalah penduduk asli yang berasal dari Melayu Tua yang mendiami anak-anak sungai Batanghari. Salah satu daerah yang menjadi jalur perkembangan adat istiadat ini adalah Batin Jujuhan.

Pada mulanya bekas Onder Afdeeling ini hanya terdiri dari beberapa daerah batin seperti, Batin Batang Tebo, Batin Jujuhan, Batin Batang Bungo, Batin Pelepat Senamat, Batin III Ilir, Batin II, Batin V, Batin III Ulu dan Batin Tanah Sepenggal (Buku Pedoman Adat Bungo,2004 :2). Artinya kampungkampung/ dusun yang dilewati aliran sungai batang Jujuhan merupakan jalur perkembangan masyarakat adat di kabupaten Bungo. Dusun Talang Silungko Kecamatan Bathin II Pelayang, adalah pecahan dari Dusun Pelayang merupakan salah satu dusun yang dilalui perkembangan masyarakat adat ini. Dari hal tersebut diatas dipertegas lagi bahwa pada prakteknya hukum adat mengatur seluruh aspek dalam kehidupan sosial masyarakat seperti ketatanegaraan, perkawinan, kekerabatan, waris, perekonomian, pertanahan dan konflik sosial.

Demikian halnya yang berkembang di kabupaten Bungo khususnya di Kecamatan Bathin II Pelayang. Selain itu, di Dusun Talang Silungko pernah terjadi konflik terutama konflik perkelahian. Menurut penuturan Hendrik selaku Ketua Pemuda Dusun Talang Silungko, bahwa "Di dusun Talang Silungko Pernah terjadi konflik antar pemuda dusun Talang Silungko dengan dusun tetangga, bermula dari saling senggolan berjoget pada waktu organ tunggal saat acara khitanan salah satu masyarakat di dusun Talang Silungko" (wawancara dilakukan 27 November 2017). Melihat hal tersebut maka, bagaimana sesungguhnya kedudukan dan peran adat dalam menyikapi persoalan yang terjadi di dusun Talang Silungko ini sehingga permasalahan ini bisa diselesaikan. Disisi lain konflik perkelahian/ cekak kelahi diatas merupakan salah satu bagian dari konflik sosial dan merupakan bagian dari materi dalam ruang lingkup adat. 
Sementara itu dipertegas dalam Buku Pedoman Adat Bungo (2004:88) menyatakan bahwa "Setiap perkara haruslah diselesaikan menurut tingkatannya. Pada tingkatan pertama, haruslah diselesaikan dulu oleh Tuo Tengganai. Jika tidak selesai, maka berjenjang naik, diteruskan ke kepala Dusun, lalu selanjutnya, jika tidak selesai juga, diteruskan ketingkat Negeri, Batin (Marga). Pada tingkat marga (Batin) maka segala perkara adat itu, harus diputuskan dan ditetapkan pula berat ringannya perkara dan menjadi tingkatan mana didenda. Dengan demikian maka, penulis tertarik untuk mendalami tentang bagaimana kedudukan serta peranan hukum adat dalam menyelesaian konflik di Dusun Talang Silungko Kecamatan Bathin II Pelayang. Maka, penelitian ini mengangkat judul "Kedudukan dan Peran Lembaga Adat dalam Penyelesaian Konflik“.

\section{METODE}

Metode penelitian yang gunakan adalah dengan pendekatan deskriptif kualitatif. Penelitian kualitatif dilakukan secara intensif, peneliti ikut berpartisipasi lama di lapangan, mencatat secara hatihati apa yang terjadi, melakukan analisis reflektif terhadap berbagai dokumen yang ditemukan di lapangan, dan membuat laporan penelitian secara mendetail. Adapun data primer dalam penelitian ini yaitu data tentang Pelaksanaan hukum adat dalam kaitannya untuk Perumusan Kebijakan Lembaga Adat Dusun Talang Silungko Kecamatan Bathin II Pelayang. Data sekunder merupakan data/ informasi pendukung penelitian berupa informasi-informasi, arsip, buku, dokumen, studi literatur yang dikumpulkan melalui berbagai sumber, media massa, peraturan daerah/ kebijakan pemerintah daerah dan kajiankajian penelitian terdahulu meliputi skripsi, tesis, disertasi, laporan penelitian serta jurnal yang relevan yang berkaitan dengan pelaksanaan hukum adat di dusun Talang Silungko Kecamatan Bathin II Pelayang. Teknik pengumpulan data dalam penelitian ini terdiri atas : 1) Observasi, 2) Wawancara, 3) Dokumentasi.

Penentuan informan pada penelitian ini dilakukan dengan teknik Sampling purposive, dimana pemilihan dilakukan secara sengaja berdasarkan kriteria yang telah ditentukan dan ditetapkan berdasarkan tujuan penelitian.

\subsection{Tabel Informan penelitian}

\begin{tabular}{ccc}
\hline No & Nama Informan & Jumlah \\
\hline 1 & Ninik Mamak Dusun Talang Silungko & 2 \\
2 & Kepala Desa (Rio) Dusun Talang Silungko & 1 \\
3 & Ketua Lembaga Adat Kecamatan Bathin II Pelayang & 1 \\
4 & Ketua Lembaga Adat Dusun Talang Silungko & 1 \\
5 & Pegawai Sara' / Imam Masjid & 1 \\
6 & Ketua Pemuda Dusun Talang Silungko & 1 \\
7 & Polsek Bathin II Pelayang & 1 \\
& Total & 8 \\
\hline
\end{tabular}

Teknik analisis data yang digunakan dalam penelitian ini adalah menggunakan teknik analisis data model Spradley. Spradley mengemukakan dalam Sugiyono (2012: 343) membagi analisis data dalam penelitian kualitatif berdasarkan tahapan dalam penelitian kualitiatif. Tahapan analisis data yang dilakukan dalam penelitian kualitatif, yaitu analisis domain, analisis taksonomi dan analisis komponensial, analisis tema kultural (Sugiyono, 2012: 345). 
Teknik analisis data model Spradley ditunjukkan dalam gambar berikut ini: Gambar 1: Tahapan analisis kualitatif model Spradley

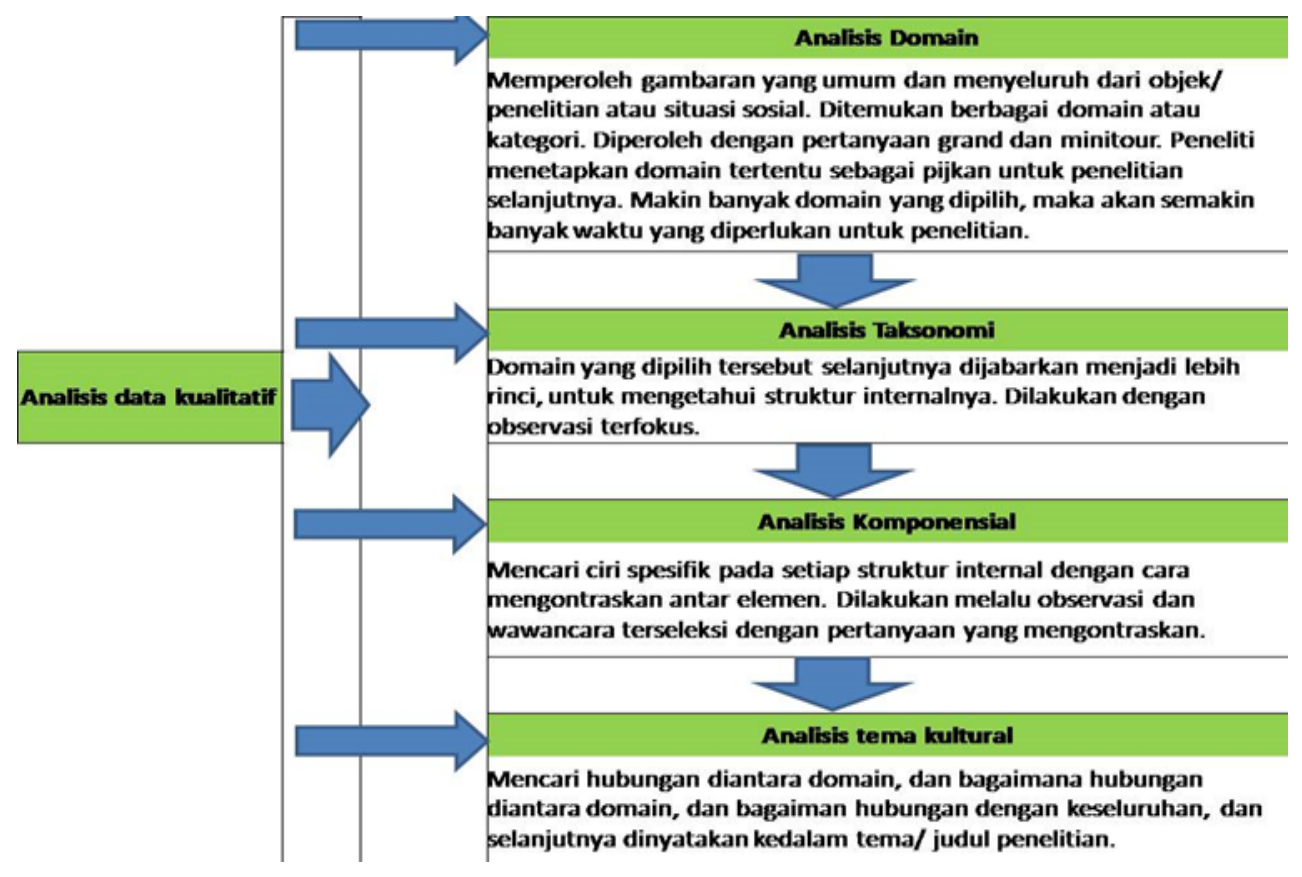

Sumber: Sugiyono, 2012: 346

Analisis data dalam penelitian ini adalah sebagai berikut:

Pertama, analisis domain yakni menganalisa dan memahami data-data berupa dokumendokumen, arsip-arsip, maupun catatan-catatan yang diperoleh dari dusun Talang Silungko Kecamatan Bathin II Pelayang serta dari berbagai sumber media. Dari proses tersebut, kemudian dapat diketahui gambaran umum dan maksud dari data-data tersebut.

Kedua, analisis taksonomi menganalisa dan memahami data-data hasil observasi terfokus terkait dengan tentang kedudukan dan peranan hukum adat dalam kaitannya untuk Penyelesaian suatu masalah di dusun, dan hambatan-hambatan yang dihadapi oleh Lembaga Adat Dusun Talang Silungko Kecamatan Bathin II Pelayang serta upaya yang dilakukan oleh Lembaga Adat Kecamatan Bathin II Pelayang dalam menyelesaikan konflik. Dari proses tersebut, kemudian dapat diketahui secara rinci makna dan maksud dari data-data tersebut. Ketiga, analisis kompersial yakni menganalisa dan memahami hasil wawancara yang telah dilakukan terhadap informan penelitian. Data yang dikumpulkan dengan cara observasi dan interview yang mendalam dari sumber data yang sesuai dengan level pendekatannya. Dari proses tersebut, kemudian dapat diketahui makna dan maksud dari jawaban para informan tersebut.

Keempat, analisis tema kultural yakni menggabungkan berbagai analisa dan pemahaman yang telah diperoleh tersebut. Data dari sampel pertama langsung dianalisis dengan mencoba mencari penjelasan secara komprehensif terhadap kedudukan dan peranan hukum adat dalam kaitannya untuk menyelesaikan konflik, dan hambatan-hambatan yang dihadapi oleh Lembaga Adat Kecamatan Bathin II Pelayang serta upaya yang dilakukan oleh Lembaga Adat Dusun Talang Silungko Kecamatan Bathin II Pelayang dalam perumusan kebijakan publik oleh Lembaga adat Dusun, sehingga dapat diketahui kesimpulan kedudukan dan peranan hukum adat, hambatan dan upaya yang dilakukan dalam perumusan kebijakan publik tersebut. 


\section{HASIL DAN PEMBAHASAN}

Kedudukan merupakan tempat atau letak dimana sesuatu untuk ditempatkan sebagaimana mestinya. Begitupula dengan hukum adat yakni bagaimana seyogyanya hukum adat ditempatkan atau diletakkan dalam mengatur kehidupan masyarakat adat dan masyarakat secara umumnya. Selain itu juga keberadaan hukum adat mampu diterima di tengah-tengah komunitas sosial masyarakat tertentu. Pada akhirnya hukum adat menjadi salah satu bagian terpenting dalam menyelesaikan sebuah persoalan yang terjadi di lingkungan masyarakat. Selain itu kedudukan hukum adat tersebut disini difokuskan bagaimana kedudukan dalam proses pelaksanaannya sesuai dengan fungsi hukum adat tersebut dalam konteks dan ruang lingkup masyarakat adat.

Dari data sekunder diatas yang telah diolah maka terlihat bahwa hukum adat bagi masyarakat melayu merupakan aturan yang sepenuhnya mengatur sendi-sendi kehidupan. Semua gerak-gerik masyarakat baik secara individu maupun dalam sebuah dusun atau kampung seluruhnya diatur oleh aturan adat. Dari penjelasan tersebut dapat disimpulkan bahwa kedudukan hukum adat terbagi menjadi 3 (tiga) yaitu a) Pucuk Undang; b) Hukum Publik; dan c) Hukum Privat. Namun demikian, ketiganya mempunyai ruang atau wilayanh pengaturannya masing-masing, sehingga dalam mengimplementasikan hukum adat tidak tumpang tindih.

Sementara itu menurut penuturan Ketua Lembaga Adat Dusun Talang Silungko Bapak Ishak.J bahwa "Karena hukum adat tersebut berasal dari syara' (ajaran agama). Benar kato syara' pastilah benar kato adat" (wawancara tanggal 22 April 2018). Artinya bahwa Sesungguhnya hukum adat merupakan hukum yang secara tidak langsung merupakan bagian dan ada keterkaitannya dengan hukum agama (islam). Jadi masyarakat yang menjunjung tinggi nilai-nilai agama, maka mereka juga menjunjung tinggi nilai-nilai hukum adat dalam kehidupan masyarakat tersebut. Hal tersebut diperkuat oleh pendapat yang disampaikan oleh M.Nasir.L selaku Ketua Lembaga Kecamatan bahwa "Ciri-ciri daerah tersebut menggunakan hukum adat dapat dilihat dari penerapan agama di dalam kehidupan sehari -hari. Nah apabila suatu daerah itu taat terhadap agama, namun secara tidak langsung mereka menggunakan hukum adat di dalam kehidupan sehari-harinya" (wawancara tanggal 23 April 2018).

Dari penjelasan tersebut telah jelas bahwa hukum adat di Kecamatan Bathin II Pelayang masih sangat relevan baik kedudukan maupun fungsinya sebagai hukum yang mengatur tentang sendisendi kehidupan termasuk terkait dengan konflik. Apalagi, masyarakat hukum adat dalam suatu wilayah dusun atau kampung saat ini sudah tidak seutuhnya masyarakatnya melayu. Hukum adat riskan dipertahankan kutuhannya baik oleh masyarakat selaku pemangku adat maupun generasi penerus yang terus menjunjung tinggi adat sebagai landasan dalam melaksanakan kehidupannya sehari-sehari.

Adapun peranan hukum adat dalam menyelesaikan konflik perkelahian adalah sebagaimana diatur dalam Undang Nan Duo Puluh berikut ini:

1. Tikam Bunuh Padang Berdarah

Tikam Bunuh Padang Berdarah adalah suatu perbuatan dengan sengaja menikam, menusuk, memukul dan perbuatan selesai dengan akibatnya, mungkin luka laju mati, luka berat sakit parah, luka ringan sakit sementara, maka dijelaskan sebagai berikut:

a. Tikam, adalah suatu perbuatan dengan sengaja melakukan menikam, menusuk, mengapak, memukul dengan alat atau senjata. Unsur dan akibatnya jangat lanteh, darah tapacak, daging takuak, urat putus, tulang rakuk atau patah dan orang menjadi sakit.

b. Bunuh, adalah suatu perbuatan dengan sengaja menghilangkan nyawa orang lain, bangkai taguling mayat tabujao, mungkin mati ditempat, mati dalam sempit seko (tiga hari), mati dalam lapang seko (tujuh hari), mati dalam lungkang seko (dua kali tujuh hari).

Kedua hal tersebut bentuk hukumannya yakni sebagai berikut:

1. Jika lebam balu dikenokan denda tepung tawa;

2. Jika luko tekuak, dikenokan kambing sikuk, beras dua puluh gantang, kain empat kayu, lengkap dengan selemak manis, seasam segaramnya;

3. Jika luko segaris dikenokan ayam, beras segantang, yang dinamokan nasi putih kuah kuning; dan

4. Mati bangun, dikenokan kerbau sikuk, beras seratus gantang, kain delapan kayu, dilengkpi dengan selemak manis, seasam segaramnya. 


\section{Mati Dibangun Silih Mati Ganti Nan Hilang}

Mati Dibangun Silih Mati Ganti Nan Hilang artinya bahwa orang mati membiayai ahli waris yang hidup. Ada enam macam terkait hal ini (bangun) yaitu:

\section{a. Bangun setengah tigo}

Yaitu, berasal dari kata 2,5 (dua setengah) atau setengah tigo yang berarti kurang dari tiga tetapi lebih dari dua. Misalnya membunuh orang yang sedang hamil, atau satu perbuatan banyak orang yang mati sebanyak dua atau tiga orang atau lebih dan tidak mungkin membangun setiap orangnya. Dengan demikian hukuman yang diberikan kepada pelaku hanya satu saja, walaupun yang mati bayak (dua atau tiga orang). Tetapi hukum yang telah dijatuhkan tersebut telah meliputi semua korban yang mati itu maka, di jatuhkan hukum berikut: "Hukum bangun beras seratus gantang, kerbau satu ekor, dagang 20 (dua puluh) kayu kain, emas duo kati dua tahil duo pao (1.716 gram emas), kecik bebatu gedang babungkal baikou bakupalo".

b. Bangun sudah

Maksudnya yaitu, sudah ada niat untuk membunuh seseorang dan orang tersebut mati ditempat atau mati dalam tempo waktu maksimal 3 hari. Maka dihukum dengan "Hukum bangun dengan beras seratus gantang, kerbau satu ekor, dagang 12 kayu kain, emas satu kati satu kahil (840 gram), kecik bebatu gedang babungkal, baikou bakupalo".

c. Bangun sadu amat

Maksudnya yaitu, orang yang hendak dibunuh sudah mati tetapi tidak mati di tempat, tetapi mati dalam lapang seko atau lungkang seko. Maka, dihukum dengan "Hukum bangun dengan beras seratus gantang, kerbau satu ekor, dagang 10 kayu kain, emas satu kati (800 gram), kecik bebatu gedang babungkal, baikou bakupalo"

d. Bangun mayo

Maksudnya yaitu, hendak membunuh seseorang namun ternyata tidak mati hanya sakit saja. Maka, dihukum dengan "Hukum bangun dengan beras seratus gantang, kerbau satu ekor, dagang 5 kayu kain, kecik bebatu gedang babungkal, baikou bakupalo, emas seperdua kati setail (416 gram), ubat taweih ureih jampi"

e. Bangun subhat 'amat

Maksudnya yaitu, tidak ada niat atau tidak sengaja untuk membunuh namun yang terjadi justru ada seseorang yang terbunuh. Maka, dihukum dengan "Hukum bangun dengan beras seratus gantang, kerbau satu ekor, dagang 1 kayu kain, emas duo tail (80 gram), kecik bebatu gedang babungkal, baikou bakupalo"

f. Bangun khotam

Maksudnya, tidak ada ada niat hendak membunuh baik membunuh seseorang maupun binatang. Tetapi seseorang terbunuh akibat dari hak milik missal terbunuh karena digigit hewan peliharaan, tertimpa pohon ataupun tertimpa reruntuhan rumah karena ada angin kencang. Maka di hukum dengan, "Hukum bangun dengan beras seratus gantang, kerbau satu ekor, dagang 1 kayu kain, emas satu tahul (40 gram), kecik bebatu gedang babungkal, baikou bakupalo"

\section{Luko Dipampas Jangan Bataup}

Luko Dipampas Jangan Bataup ialah luko yang disebabkan oleh perbuatan orang lain. Dengan unsurnya jangat lanteih, darah tapacak, daging takuak, urat putus, tulang rakuk disebut "Salah cencang membayar pampas". Jika terjadi pada manusia, hewan dan harta benda disebut "Hilang basebab mati bakareno".

a. Luko Paling ringan (hajah) yang unsur-unsurnya seperti "kelisab jangat, darah pikat, tebit darah".

b. Luko ringan (daniah) yang unsur-unsurnya mencakup "Jangat lanteih darah tapacak".

c. Luko paling rendah (bajah) unsurnya meliputi "Jangat lanteih darah tapacak daging takuak".

d. Luko rendah (matlahamah) unsurnya meliputi "Jangat lanteih darah tapacak daging takuak". 
e. Luko berat (mudhah) unsurnya meliputi "Jangat lanteih, daging takuak, darah tapacak, urat putus, tulang rancung, atau tempeng hidung, tempeng telingo, tabukahai perut, takudung”.

f. Luko balung tinglal buwek (mahmudah) unsurnya sama seperti Luka Berat hanya saja ini tidak bisa bekerja untuk beberapa waktu.

g. Luko tinggi (dampah), luka yang biasa hanya saja luka tersebut terdapat pada bagian badan yang tidak tertutupi pakaian sehari-hari.

h. Luko tinggi balung tinggal buwek, Luka ini sama seperti Luka Tinggi hanya saja ditambah tidak bisa bekerja.

Dari beberapa aturan yang telah dijelaskan tersebut dapat disimpulkan bahwa hukum adat mengatur semua sendi kehidupan masyarakat. Denda-denda yang menjadi hukuman terhadap permasalahan yang terjadi menunjukkan bahwa semua tindakan yang salah sudah barang tentu ada konsekuensinya atau akibatnya. Dengan demikian terlihat bahwa, Hukum Adat mengajarkan kepada masyarakat akan arti kehati-hatian dalam melakukan sesuatu. Sikap atau tingkah laku yang baik akan mendapatkan hasil yang baik, sementara itu tingkah laku yang tidak baik akan mendapatkan hukuman sebagai akibat dari perbuatannya.

Di dalam kehidupan sosial masyarakat di Dusun Talang Silungko seperti hasil wawancara kepada Ketua Adat Dusun Talang Silungko Ninik Ishak.J menyatakan sebagai berikut:

"Hukum Adat juga mengatur bagaimana berpola tingkah antar sebaya, orang tua, orang yang lebih muda itu telah diatur di dalam Hukum Adat. Terhadap pemerintahan juga diatur agar roda pemerintahan tetap berjalan dengan baik para pejabat pemerintahan/ pemangku adat juga akan dikenakan sanksi apabila melakukan kesalahan, begitu juga sebaliknya. Ada aturan/ hukum adat yang namanya orang gadang berlaku kecil maksudnya disini para pejabat pemerintahan ataupun pemangku adat melanggar aturan, maka dikenakan sanksi beras 100 gantang dan kerbau seekor. Ada juga yang namanya dago-dagi yang maksudnya menentang/ memaki orang besar yang dalam hal ini para pejabat/ pemangku adat, maka dikenakan sanksi hukuman berupa beras 20 gantang dan kambing seekor" (wawancara tanggal 24 April 2018).

Berdasarkan penuturan beliau di atas dijelaskan bahwa Hukum Adat di Dusun Talang Silungko mengatur segala sendi kehidupan sosial masyarakat di dalam kehidupan sehari-hari tanpa pandang bulu, siapapun yang bersalah menurut Adat walaupun seorang pemangku adat, maka haruslah dikenakan sanksi sesuai dengan aturan adat yang berlaku.

Di tempat terpisah berdasarkan hasil wawancara dengan Mustopa selaku Ninik Mamak Dusun Talang Silungko di Dusun Talang Silungko memang Pernah terjadi konflik, terutama konflik perkelahian / cekak kelahi. Namun tidak sampai menimbulkan korban jiwa. Salah satu Peristiwa yang pernah terjadi yaitu konflik perkelahian antar pemuda Dusun dalam Dusun Talang Silungko. Berikut ini penuturan lengkapnya :

"Disini memang pernah terjadi konflik perkelahian namun sampai jatuhnya korban jiwa. Bukan berarti masyarakat disini gemar melakukan hal tersebut. Pernah terjadi konflik perkelahian disini, pada saat itu salah seorang warga Dusun Talang Silungko sedang mempunyai hajatan yaitu acara pernikahan dengan menggunakan hiburan organ tunggal. Masyarakat sekitar sangat sepi dengan hiburan rakyat, sehingga momen tersebut begitu ditunggu dan dimanfaatkan oleh pemuda - pemuda baik dari Dusun Talang Silungko ini sendiri atau pun dari dusun tetangga untuk bersuka ria.

Tetapi sangat disayangkan tidak sedikit diantara mereka menikmatinya dengan miras dan mabuk - mabukan sehingga terjadilah hal - hal yang tidak diinginkan. Sebenarnya hanya permasalahan sepele, yaitu bersenggol - senggolan saat berjoget bersama. Namun karena berada dibawah pengaruh minuman keras, perkelahian pun tak dapat di hindarkan. Akan tetapi peristiwa pada malam itu berhasil didamaikan oleh para pemuda dan perangkat dusun. Namun ternyata perkelahian tersebut masih menyisakan dendam diantara mereka, sehingga berkelanjutan setelahnya. 
Selang beberapa lama setelah peristiwa perkelahian malam itu, keduanya secara tidak sengaja kembali bertemu, kemudian berlanjutlah perkelahian tersebut yang kali ini menimbulkan korban luka salah satunya, namun perkelahian/ konflik tersebut juga di tangani oleh pihak berwajib. Konflik tersebut telah di selesaikan secara hokum adat dan kedua belah pihak telah di damaikan namun pelaku masih menerima hukum positif ( Penjara ) oleh kepolisian" (wawancara tanggal 21 April 2018).

Dalam hal ini salah seorang anggota Lembaga Adat Dusun Talang Silungko yang juga Ninik Mamak Dusun Talang Silungko yang berhasil diwawancarai yaitu Bapak Busono menjelaskan alur proses peradilan Hukum Adat yang diterapkan di Dusun Talang Silungko yaitu :

"Pelaku atau pun keluaga / kerabat Pelaku menemui kepala kampung untuk kemudian memberikan keterangan kepada kepala kampung sembari membawa dan menyerahkan "Pisau Copu" kepada kepala kampung sebagai tanda patuh. Kemudian kepala kampung mengumpulkan para perangkat dusun yang dalam hal ini Datuk Rio, Ninik Mamak, para Kepala Kampung, Ketua Lembaga Adat Dusun dan para pejabat dusun lainnya dengan menghadirkan pihak dari pelaku, korban dan saksi.

Didalam sidang peradilan ini pimpinan sidang telah dipilih sebelumnya oleh dan dari para perangkat dusun. Selama proses persidangan yang boleh memberikan pendapat, saran atau masukan hanya orang - orang yang namanya tercantum didalam " Lit " atau daftar hadir anggota sidang. Keputusan sidang diambil dan di sah kan oleh pimpinan sidang berdasarkan hukum adat yang berlaku dan juga hasil musyawarah para anggota sidang" (wawancara 25 April 2018).

Dari hasil wawancara terhadap para Ninik mamak diatas dijelaskan bahwa konflik atau perkelahian di Dusun Talang Silungko pernah terjadi namun tidak sampai menimbulkan korban jiwa, banyak faktor penyebab hal tersebut bisa terjadi. Meskipun demikian konflik - konflik tersebut tidak sampai menimbulkan korban jiwa hanya luka - luka.

Didalam kasus ini hukum adat yang diterapkan yaitu "Lluko tekuak" dikenokan kambing sikuk, beras dua puluh gantang, kain empat kayu, lengkap dengan selemak manis, seasam segaramnya;

Dari berbagai persoalan dan permasalahan terkait dengan konflik sosial termasuk di dalamnya

konflik perkelahian yang sering terjadi ditengah-tengah masyarakat maka, dalam hukum adat ada berbagai tahapan cara penyelesaian atau proses tahapan dalam menentukan hukuman terhadap seseorang yang telah melakukan kesalahan tersebut.

\section{Adapun pedoman/ tahapan tersebut yaitu sebagai berikut:
1. Sendi Hukum}

Semacam dasar hukum, dicari dasar hukumnya apa. Jadi setiap permasalahan terlebih dahulu dipelajari dasar hukumnya apa sehingga seseorang dapat dinyatakan salah atau tidak. Yang merupakan sendi hukum dalam adat yaitu:

a. Hukum syarak, kitabullah sebagai pedoman/ petunjuk;

b. Hukum adat, yang takluk kepada adat yang lazim, puseko nan kawi; dan

c. Hukum nasional, yang berpedoman kepada undang-undang;

2. Dasar Hukum

Merupakan pertimbangan yang digunakan untuk menjatuhkan hukuman oleh Majelis Adat dalam sebuah perkara adalah dengan memperhatikan hal berikut:
a. Hukum Syarak;
b. Hukum Adat;
c. Hukum Nasional; dan
d. Hukum Akal.

Ini merupakan tahapan yang dilakukan dengan memilih dasar hukum mana yang akan diterapkan kepada seseorang yang melakukan kesalahan. 


\section{Bentuk Hukuman}

Setelah diketahui dasar hukumnya maka selanjutnya adalah ditentukan apa bentuk hukuman yang tepat dijatuhkan kepada seseorang yang telah melakukan kesalahan tersebut. Ada beberapa bentuk hukuman dalam hukum adat yakni hukum merajo sikso, hukum lamo, hukum sempurno, hukum bersamo, hukum ramo-ramo dan hukum bendo.

4. Warna Kesalahan

Warna Kesalahan merupakan sesuatu hal yang dilakukan tersebut sesuai dengan besar kecilnya kesalahan. Jika kesalahan tersebut dinilai besar maka warna kesalahan hitam. Namun jika kesalahan tersebut dinilai kecil maka warna kesalahan putih.

5. Pintu salah

Bagaimana motivasi seseorang dalam melakukan kesalahan/ tindakan salah. Pintu salah tersebut bisa karena sudah ada niat untuk berbuat salah atau tidak disengajan berbuat salah.

6. Tanda-tanda untuk menyatakan kesalahan

Untuk menetapkan apakah telah terjadi kesalahan atau seseorang telah melakukan kesalahan sehingga dapat didakwa maka sebaiknya memeprhatikan tanda-tandanya sebagai berikut:

Enam dulu tando bukti (pembuktian) mencakup: tekeja-telelah, tepekik-tepingkau, tecencangtetepau, tetando-tebukti, teikat-tekungkung dan tetangkap tangan-tepegang kaki.

Enam kemudian tando untuk mendakwa mencakup: bejalan begegeh-gegeh, bejejak-beunut, tebayak-tetabu, cenderung mato orang banyak, bejalan bebasah-basah dan enggang lalu ranting patah.

7. Saksi-saksi

Penentuan saksi sebaiknya seorang yang adil bukan orang tamak, bukan orang yang kanakkanakan serta bukan ibu bapaknya atau keluarganya.

8. Dakwa yang ma'ruf

Meliputi apa saja, selanjutnya dakwa terbagi dalam dua bagian yaitu dakwa terhadap orang hidup dan dakwa terhadap orang yang mati.

9. Penyerahan tanda patuh

Hal ini dilakukan jika terjadi silang selisih atau cekak berkelahi namun masih dalam satu batin, maka menurut adat yang teico tepakai persoalan tersebut diselesaikan dengan Tuo Tengganai kampung. Seperti seloko adat berikut: "Kok keruh nan setampuk pinang, kok kusut nan sebatang gelindan". Artinya selama selisih atau cekak berkelahi itu masih dalam satu keluarga. Namun jika perselisihan tersebut tidak bisa diselesaikan oleh Tuo Tengganai bisa saja perkara tersebut diselesaikan pada jenjang yang lebih tinggi. Seperti bunyi seloko adat berikut: "Bejenjang naik betanggo turun". Perkara tersebut selanjutnya diserahkan ke batin memakai Tando Patuh. Menurut Ketua Lembaga Kecamatan Bathin II Pelayang M.Nasir.L dalam sebuah wawancara menjelaskan yang dimaksud Tando Patuh yaitu "Tando Patuh menurut adat di Kabupaten Bungo ada tiga yakni tando lembago, tando pasko dan tando undang" (wawancara tanggal 22 April 2018).

10. Sidang Nenek Mamak

Sidang Nenek Mamak dipimpin langsung oleh Batin. Karena menurut adat Batin merupakan Pemegang Adat, nan rimbun dek adat, rindang dek pesko.

Sidang Nenek Mamak terdiri dari Majelis Adat yang keanggotaanya terdiri dari Nenek Mamak, Alim Ulama, Cerdik Pandai. Sementara itu perangkat Batin bertindak sebagai panitera sidang.

11. Tata cara sidang Merupakan ketentuan yang disepakati bersama dalam melaksanakan sidang perkara. Sidang dianggap sah jika telah memenuhi syarat-syarat yang telah ditentukan.

12. Pemeriksaan Perkara Pemeriksaan Perkara dilakukan untuk memeriksa lebih lanjut apakah perkara tersebut termasuk kesalahan besar atau kesalahan kecil. Kemudian mengkaji wewenang memutus perkara dan menentukan perkara manakah yang sedang disidangkan itu. 


\section{Makan Kecundang}

Ini merupakan tahapan terakhir dalam memutus sebuah perkara/ permasalahan yang dilakukan seseorang yang melanggar adat. Apabila sidang sudah selesai memeriksa perkara, menetapkan hukuman, kata sudah putus dan sudah ditentukan adat yang akan diisi serta lembago yang akan dituang dan telah ditetapkan pula jangka waktunya maka, ditetapkan pula satu acara khusus yang akan diadakan pada hari tertentu. Acara khusus tersebut adalam makan bersama kedua belah pihak bersama Nenek Mamak kedua belah pihak untuk memperbaiki dan mendamaikan kedua belah pihak yang berperkara.

Walau demikian, sesungguhnya ada cara untuk mencegah segala sesuatu yang buruk terjadi yakni dengan cara yang dilakukan preventif oleh Nenek mamak dalam sebuah dusun atau kampung tertentu. Hal ini dilakukan agar kejahatan betul betul tidak terjadi, sehingga tindakan ini terus menerus dilakukan. Selain itu tujuan lainnya yaitu karena Nenek mamak sesungguhya yang mengawasi ketentraman dan ketenangan masyarakat. Hal ini juga dipertegas oleh Nenek mamak Dusun Talang Silungko dalam sebuah seloko sebagai berikut "Tidak ado pialang memecah timbo tidak ado biduk pengeruh rantau, ingkar boleh hingga suku keras hingga rajo". Artinya bahwa, tetangga terasa aman, sekampung selalu damai, alam selalu bersahabat tidak ada kekhawatiran dari gangguan binatang buas dan lain sebagainya.

Adapun tindakan preventif dan tindakan penengah yang dilakukan oleh Nenek mamak dan pemangku adat adalah sebagai berikut:

Ambek sako empang mati

Maksudnya adalah setiap kejahatan dilarang betul-betul, dihambat, tidak boleh terjadi sama sekali, keadaan ini sering disebut dalam istilah adat yaitu "Terumpung tidak boleh hilir, seluang tidak boleh mudik”. Semua jalan kejahatan ditutup secara hukum, dicegah, dihambat agar tidak meluas ditiru orang lain. Dalam hal ini Nenek mamak dan pemangku adat berfungsi menjadi "sapieh erai" dengan cara mencegat, memanggil, menegur pelaku kejahatan dan korban kejahatan untuk selalu menahan diri agar menunggu penyelesaian dari pemangku adat dan agar tidak meluas.

Perbuatan "sapieh erai" merupakan sitawar sidingin yang efektif untuk mencegah kejahatan baru yang disebabkan oleh dendam atau emosi dari pihak keluarga korban ini dinamakan dalam seloko adat "Ambek sako empang mati" yaitu mencegah main hukum rimba, siapa kuat dialah yang menang, siapa cepat dialah yang dapat sehingga tidak ada azas keadilan.

Menengahi pelanggaran

Maksudnya yakni dalam suatu pelanggaran, pemangku adat melakukan "sapieh erai”dengan cara mencegat dan dibawa ke sidang rapat perkara adat dengan anggota orang tuo, cerdik pandai dan alim ulama untuk mengkaji dan meneliti kejahatan tersebut. Seperti dalam istilah adat "Kaji sampai keembun padu baco sampai kekesik jinim, dicuci sehabis air dikikis sehabis besi, ditakik darah ketiang dicari kutu keijuk, bertemu ruas dengan buku, bertemu data dengan fakta, sudah terang bak matohari bergelanggan mato orang banyak, sudah terbukti dengan nyata". Dengan demikian setelah dilakukan pengkajian selanjutnya hakim perkara adat mufakat bulat mengambil keputusan dan putusan itu dijatuhkan oleh pemangku adat kepada pelaku pelanggaran.

Juru damai adat

Maksudnya yaitu, dalam suatu pelanggaran yang di "sapieh erai" ditengahi oleh pemangku adat bahwa yang salah disalahkan dan yang benar dibenarkan, selanjutnya dijatuhkan hukuman yang setimpal dengan pelanggaran yang dilakukannya dihadapan wakil pelaku pelanggaran atau "suku tenganai".

Waktu dijatuhkan hukuman dan putusan disampaikan, "suku tenganai” berkata air akan dihilir dan kalam akan dijalankan selanjutnya dilaksanakan acara makan salah diikuti dengan perdamaian antara kedua belah pihak.

Dengan masih relevannya penerapan Hukum Adat di Dusun Talang Silungko Kecamatan Bathin II Pelayang ini mendapatkan apresiasi dari Iptu. Faisol Kifli selaku Kapolsek Pelayang melalui Aiptu. Hairi, beliau menuturkan bahwa : 


\begin{abstract}
"Kami dari pihak Kepolisian sangat mendukung dengan masih diterapkannya atau masih sangat kentalnya penerapan Hukum Adat disini. Karena secara tidak langsung kami merasa terbantu didalam menyelesaikan suatu delik yang terjadi disini" (wawancara tanggal 02 Mei 2018)
\end{abstract}

Dari penjelasan diatas dapat disimpulkan bahwa pihak berwajib merasa sangat terbantu dengan masih kentalnya penerapan Hukum Adat di Dusun Talang Silungko terutama didalam menyelesaikan konflik perkelahian. Karena masyarakat di Dusun Talang Silungko lebih mengutamakan unsur kekeluargaan didalam menyelesaikan suatu perkara. Namun jika perselisihan tersebut tidak bisa diselesaikan secarar kekeluargaan yang dalam hal ini oleh Hukum Adat bisa saja perkara tersebut diselesaikan di jenjang yang lebih tinggi atau bahkan ke Kepolisian. Seperti bunyi seloko "Bejenjang naik betanggo turun". jri ) seperti barikut ini:

Sementara itu, dituturkan pula oleh tokoh masyarakat Dusun Talang Silungko (Bapak Alpa-

"Masyarakat disini memang masih kental di dalam menerapkan nilai-nilai adat, semua permasalahan yang pernah terjadi disini apapun itu, tetap mengutamakan hukum adat didalam menentukan solusinya. Karena didalam peraturan adat tersebut sudah lengkap semua di dalam mengatur tentang tingkah pola dan perilaku di dalam kehidupan sehari -hari" (wawancara tanggal 02 Mei 2018).

Demikian begitu jelas peran hukum adat di Dusun Talang Silungko ini baik dalam upaya mencegah perbuatan yang melanggar hukum maupun upaya menyelesaikan persoalan terutama terkait dengan konflik. Dari proses hulu hingga hilir hukum adat di Dusun Talang Silungko ini begitu diutakaman. Oleh sebab itu, tidak heran jika suasana dalam kehidupan sehari-hari selalu menjunjung tingi nilainilai adat.

yakni:

Bukan hanya itu saja, Ketua Pemuda Dusun Talang Silungko juga menyatakan hal serupa

"Disini memang bisa dikatakan pernah terjadi konflik terutama konflik perkelahian / cekak kelahi. Baik itu antar pemuda, antar anak-anak yang sampai ke orang tua nya, $\mathrm{dsb}$. Meskipun demikian kami disini lebih mengutamakan penyelesaian melalui Adat. Namun bukan berarti kami disini tidak mengindahkan hukum positif, kami merasa alangkah baiknya selama permasalahan tersebut bisa diselasaikan melalui adat maka hukum adat lah solusinya, karena lebih bersifat kekeluargaan. Namun tidak menutup kemungkinan dibawa ke ranah hukum dan diselesaikan pihak kepolisian" (wawancara tanggal 04 Mei 2018)..

Dari berbagai kasus yang telah terjadi di Dusun Talang Silungko maka, terlihat jelas sekali bahwa hukum adat masih eksis digunakan dalam menyelesaikan berbagai konflik baik konflk sosial maupun konflik perkelahian. 
Vol 1, No 1, Juni 2019, pp. 17-29

\section{KESIMPULAN}

Kedudukan Hukum Adat Di Dusun Talang Silungko terbagi menjadi 3 (tiga) yaitu Pucuk Undang, Hukum Publik dan Hukum Privat. Namun demikian, ketiganya mempunyai ruang atau wilayanh pengaturannya masing-masing, sehingga dalam mengimplementasikan hukum adat tidak tumpang tindih. Secara tegas memberi pemahaman bahwa kedudukan adat itu di bawah hukum Agama (Islam) atau syarak. Selanjutnya, peranan hukum adat dalam menyelesaikan konflik di dusun Talang Silungko Kecamatan Bathin II Pelayang telah diatur dalam Undang Nan Duo Puluh mencakup beberapa hal yakni: Pertama Tikam Bunuh Padang Berdarah artinya suatu perbuatan dengan sengaja menikam, menusuk, memukul dan perbuatan selesai dengan akibatnya, mungkin luka laju mati, luka berat sakit parah, luka ringan sakit sementara. Kedua Mati Dibangun Silih Mati Ganti Nan Hilang artinya bahwa orang mati membiayai ahli waris yang hidup. Ketiga Luko Dipampas Jangan Bataup luko yang disebabkan oleh perbuatan orang lain. Sementara itu, Pelaksanaan hukum adat di dusun Talang Silungko Kecamatan Bathin II Pelayang telah dijalan dengan sebaik-baiknya, sehingga ada beberapa hal yang dilakukan sebagai bentuk tindakan preventif dan tindakan penengah yang dilakukan oleh Ninik mamak dan pemangku adat dalam menangani konflik yaitu: Pertama Ambek Sako Empang mati ialah setiap kejahatan dilarang betul-betul, dihambat, tidak boleh terjadi sama sekali. Kedua Menengahi Pelanggaran yakni dalam suatu pelanggaran, pemangku adat melakukan "sapieh erai"dengan cara mencegat dan dibawa ke sidang rapat perkara adat dengan anggota orang tuo, cerdik pandai dan alim ulama untuk mengkaji dan meneliti kejahatan tersebut. Ketiga Juru Damai Adat yaitu, dalam suatu pelanggaran yang di "sapieh erai" ditengahi oleh pemangku adat bahwa yang salah disalahkan dan yang benar dibenarkan, selanjutnya dijatuhkan hukuman yang setimpal dengan pelanggaran yang dilakukannya dihadapan wakil pelaku pelanggaran atau "suku tenganai". Hambatan-hambatan yang dihadapi oleh Lembaga Adat Kecamatan Bathin II Pelayang antara lain : pertama adanya sedikit pro dan kontra didalam penerapan dilapangan dan itu merupakan hal yang wajar didalam kehidupan bermasyarakat. Kedua belum memiliki dana sendiri atau dana rutin. Adapun upaya yang dilakukan oleh Lembaga Adat Kecamatan Bathin II Pelayang didalam mengatasi hambatan-hambatan diatas antara lain :Pertama melakukan pendekatan lebih intens kepada masyarakat dengan mengadakan kegiatan-kegiatan yang bersifat positif dan kekeluargaan sehingga dapat memperkecil kemungkinan hal-hal yang tidak diinginkan terjadi, kedua menjaga hubungan baik dengan para ulama dan pemerintah, ketiga sejauh ini tentang pendanaan hanya mengajukan proposal-proposal ke perusahaan-perusahaan yang ada disekitar Kecamatan Bathin II Pelayang 


\section{DAFTAR PUSTAKA}

\section{Buku-buku}

[1] Hadikusumah, Hilman. 2003. Pengantar Ilmu Hukum Adat Indonesia, Bandung : Mandar Maju.

[2] Silalahi, Ulber. Metode Penelitian Sosial Kuantitatif, Bandung : Refika Aditama.

[3] Pruitt, G. Dean dan Rubin. 2004. Teori Konflik Sosial, Yogyakarta : Pustaka Pelajar.

[4] Soekanto, Soerjono. 2013. Hukum Adat Indonesia, Jakarta : Rajawali Perss.

[5] Sudiyat, Iman. 2010. Asas-Asas Hukum Adat: Bekal Pengantar, Yogyakarta : Liberty.

[6] Badan Statistik Indonesia. 2017. Bathin II Pelayang dalam Angka, Statistik Kab.Bungo

\section{Peraturan Perundang-undangan}

[1] Undang-undang Dasar tahun 1945.

[2] Lembaga Adat Kabupaten Bungo, 2004. Buku Pedoman Adat Bungo, Kabupaten Bungo. 